\title{
Tablet and Powder for Oral Solution Dosage Form
}

National Cancer Institute

\section{Source}

National Cancer Institute. Tablet and Powder for Oral Solution Dosage Form. NCI

Thesaurus. Code C149977.

Tablet and powder, both containing active substance(s), intended for the preparation of an oral solution by dissolving the tablet and the powder in the specified liquid. 